\title{
KAJIAN KONSEPTUAL TENTANG PEMILIHAN ALLAH DALAM ROMA 9
}

\author{
Julian Frank Rouw \\ Sekolah Tinggi Teologi Kanaan Nusantara \\ J1. Kyai Sono No. 2, Genuk, Ungaran Barat, Genuk, Semarang, Jawa Tengah 60242 \\ Email: julianrouw@yahoo.com
}

\begin{abstract}
Julian Frank Rouw, Conceptual Review of God's Elections in Rome 9. Rejection of Israel as God's chosen nation, and justification of the Gentiles by faith is in the sovereignty of God. Paul explains God's act toward His chosen people in the past, in which Israel is distancing itself from God's mercy and neglecting its opportunity. In the present, Israel as a nation rejects the Messiah. In the future, Israel as a nation, will receive the Messiah and enjoy the promised blessings with the oath promise in the Old Testament. The key pressure of this context is that God's sovereignty is expressed in a vacuum, not a mere power. The choice of God's sovereignty is not based on an early knowledge of the choices and actions that humans will take in the future. However, God chooses to bless the unworthy through his faith (not on the basis of his achievement). God knows everything but He chooses to limit His choice in mercy and in promise. The human response must exist, but it follows and ultimately affirms the life-changing choice of God. On the sovereignty of God who has chosen who is chosen it can force us to draw the conclusion that God is 'unfair'. Paul has said that God's election is not bound to a lineage, that God is free to choose some of Abraham's offspring and reject some of the others.
\end{abstract}

Keywords: God's Choice, God's Sovereignty, God's Justice, Faith, Rome

ABSTRAK: Julian Frank Rouw, Kajian Konseptual Tentang Pemilihan Allah Dalam Roma 9. Penolakan Israel sebagai bangsa Pilihan Allah, dan pembenaran orang-orang bukan Yahudi karena iman ada dalam kedaulatan Allah. Paulus menjelaskan tindakan Allah terhadap umat pilihan-Nya di masa lalu, dimana Israel sebagai menjauhkan diri dari kemurahan Allah dan mengabaikan kesempatannya. Di masa sekarang, Israel sebagai suatu bangsa menolak Mesias. Pada masa yang akan datang, Israel sebagai suatu bangsa, akan menerima Mesias dan menikmati berkat-berkat yang telah dijanjikan dengan janji sumpah di Perjanjian Lama. Tekanan kunci dari konteks ini adalah bahwa kedaulatan Allah dinyatakan dalam kemurahan, bukan kekuasaan semata-mata.Pilihan kedaulatan Allah tidak didasarkan atas pengetahuan dini akan pilihan-pilihan dan tindakan yang akan diambil oleh manusia di masa yang akan datang. Namun, Allah memilih untuk memberkati orang yang tidak layak melalui imannya (bukan atas dasar prestasinya). Allah mengetahui segala perkara namun Ia memilih untuk membatasi pilihan-Nya dalam kemurahan dan dalam janji. Tanggapan manusia harus ada, namun ini mengikuti dan akhirnya meneguhkan pilihan Allah yang mengubahkan kehidupan. Atas kedaulatan Allah yang telah memilih siapa yang dipilih hal itu dapat memaksa kita menarik kesimpulan bahwa Allah 'tidak adil'. Paulus telah mengatakan bahwa pemilihan Allah tidak terikat pada suatu garis keturunan, bahwa Allah bebas memilih sebagian keturunan Abraham dan menolak sebagiannya yang lain.

Kata Kunci: Pilihan Allah, Kedaulatan Allah, Keadilan Allah, Iman, Roma

\section{PENDAHULUAN}

Roma 9 adalah salah satu bagian dalam Perjanjian Baru yang paling kuat mengenai kedaulatan Allah. Pasal 10 berfokus pada tanggungjawab manusia, menyatakan kehendak bebas manusia. Sedangkan pasal 11 menyatakan maksud penebusan Allah yang abadi dan mencakup semua. Penggunaan 25 kutipan dari Perjanjian Lama dalam pasal 9-11 menunjukkan keinginan Paulus untuk menggambarkan paradoks Israel tersebut dari Perjanjian La- ma, sebagaimana dalam pasal 4. Mayoritas dari keturunan jasmani Abraham telah menolak Allah, bahkan sejak di masa lampau (Kis. 7; Neh. 9).

Paulus menjelaskan maksud penebusan seluruh umat manusia, yang pada mulanya tampak sepertinya Allah memilih beberapa orang dan menolak yang lainnya (Calvinisme Supralapsarian), namun demikian, fokusnya bukanlah pada pribadi demi pribadi, melainkan pada rencana penebusan Allah yang abadi, seperti ditulis oleh Joseph A. Fitzmyer dan 
Raymond E. Brown, "Pentinglah untuk menyadari sejak semula bahwa sudut pandang Paulus adalah sekelompok, ia tidak mendiskusikan tanggung jawab dari pribadi-pribadi. Bila nampaknya ia mengemukakan pertanyaan mengenai predestinasi Ilahi, ini tidak ada hubungannya dengan predestinasi dari seseorang kepada kemuliaan"1 Pasal ini Paulus memberi jawaban mengenai keberatan orang Yahudi terhadap keberadaan mereka yang ditolak dalam kerajaan Allah akibat ketidakpercayaan mereka terhadap Kristus. Sanggahan Paulus ini sekaligus menjelaskan ajarannya mengenai predestinasi, yang telah disampaikan sebelumnya (Rm. 8:28).

Rumusan masalah dalam penelitian ini adalah bagaimana konsep tentang pemilihan Allah dalam Roma pasal 9. Tujuan dari penelitian ini adalah untuk melakukan kajian terhadap Roma 9 tentang pemilihan Allah. Tujuan penelitian adalah untuk menjelaskan konsep pemilihan Allah dalam Roma 9.

\section{METODE}

Metode yang digunakan dalam penelitian ini adalah kualitatif dengan kajian konteks. Objek penelitian adalah Roma 9. Penulis menafsirkan konteks Roma 9 mengikuti maksud si penulis asli pada tingkat paragraf. Pembagian paragraf ini didasarkan atas konteks dari Roma 9. Pemisahan paragraf adalah merupakan kunci untuk bisa mengikuti maksud penulis asli, yang adalah inti dari penerjemahan. Setiap paragraf memiliki satu kebenaran utama, atau kalimat topik atau ide sentral dari tulisan. Setiap paragraf hanya memiliki satu dan satu pokok saja. Pokok pemikiran ini adalah kunci dari penafsiran kesejarahan dan ketata-bahasaan. Mengikuti aliran logika dari suatu pokok bahasan yang dikemukakan oleh penulis asli, penerima ilham.

Penulis membaca Roma 9, mengidentifikasi pokok-pokoknya. Kemudian dengan membanding-

${ }^{1}$ Joseph A. Fitzmyer dan Raymond E. Brown, The Jerome Biblical Commentary, vol. 2 "Perjanjian Baru" suntingan Joseph A. Fitzmyer dan Raymond E. Brown. kan beberapa terjemahan modern antara lain (NASB, NKJV, NRSV, TEV, NJB) penterjemahan kata demi kata atau frasa untuk mendapatkan makna sesuai maksud penulis. Dengan memperbandingkan beberapa terjemahan modern ini dengan teori penerjemahan dan sudut pandang teologis yang berbeda, bisa menganalisis kemungkinan struktur pemikiran dari penulis asli.

\section{HASIL DAN PEMBAHASAN}

\section{Kesedihan Hati Paulus Karena Ketegaran Hati Orang Yahudi (Pasal 9:1-5)}

Paulus mengungkapkan perasaan dengan suatu pernyataan yang mendalam. "Aku mengatakan kebenaran dalam Kristus", sebagai suatu pernyataan yang mendalam ${ }^{2}$. Kedua ayat ini, membentuk satu kalimat dalam bahasa Yunani. "Kata-kata "suara hatiku turut bersaksi dalam Roh Kudus" merupakan anak kalimat, bentuknya (genetivus absolutus) memperkuat kesan bahwa isi (ayat 2) harus dihubungkan dengan "aku mengatakan kebenaran". 3 Paulus sedang memberikan beberapa alasan bahwa ia mengatakan kebenaran: (1) Penyatuannya dengan Kristus, ay 1 ; (2) Hati nuraninya yang dipimpin Roh, ay 1; dan (3) Perasaannya yang mendalam bagi Israel, (ay 2). " "Aku mengatakan kebenaran dalam Kristus, aku tidak berdusta." Kalimat pokok ${ }^{5}$ (aku mengatakan kebenaran). Paulus ingin menyatakan perhatianya, dengan menyatakan kebenaran dan suara hatinya. Kata kebenaran sendiri menggunakan avlh,qeia aletheia objectively, (benar, sungguh-sungguh, kebenaran, kebenaran). Dalam bahasa Yunani, kedua kata ini "dukacita" dan "kesedihan", tidak berbeda

\footnotetext{
${ }^{2}$ Matthew Henry, Tafsiran Surat Roma, 1 \& 2 Korintus (Surabaya: Momentum, 2015), 226

${ }^{3}$ Th. Van Den End, Tafsiran Surat Roma (Jakarta: BPK Gunung Mulia, 1995), 480

${ }^{4}$ Bob Utley, Kumpulan Komentar Panduan Belajar Perjanjian Baru Vol. 5 (Marshall Texas: Bible Lessons International, 2010) 178.

${ }^{5}$ Ibid, 481
} 
artinya. ${ }^{6}$ Pada dua ayat ini mengandung arti kepribadian Paulus yang telah mengetahui kebenaran secara objektif tetapi hatinya sangat sedih dan dukacita tiap-tiap hari.

Paulus memiliki perasaan yang mendalam bagi bangsanya, Israel, sehingga jika pemisahannya dapat mempengaruhi pencakupan mereka, Ia bersedia. “Aku mau terkutuk' dalam bahasa aslinya avna, qema anathema (ks) dari terjemahan dari bahasa Ibrani Kherem, terkutuk, ${ }^{7}$ (suatu hal mempersembahkan kepada Tuhan tanpa harapan ditebus), yang berarti Paulus menyatakan satu tindakan mempersembahkan dirinya agar tidak ditebus untuk sebangsaku dalam hal ini Israel karena jelas bahwa Paulus dari suku Benyamin. Ayat ini mempunyai pengembangan ketatabahasaan yang sedemikian tegas dan kuatnya dengan baik autos dan egō. ${ }^{8}$ Intensitas dan beban dari doanya sangat mirip dengan hasrat dari doa syafaat Musa bagi orang Israel yang berdosa dalam Keluaran 32:30-35. Ini harus dimengerti sebagai pernyataan keinginan, bukan fakta. ${ }^{9}$ Ini senada dengan penggunaan dari Galatia 4:20. Dasar etimologi dari "kudus" adalah dipisahkan bagi Allah untuk dipakai-Nya. ${ }^{10}$ Konsep yang sama berhubungan dengan kata ini namun bagi " kutukan". Sesuatu atau seseorang dipisahkan bagi Allah. Ini bisa merupakan suatu pengalaman positif (Im. 27:28; Luk. 21:5) atau suatu pengalaman negatif (Yos. 6-7; Rm. 9:3), tergantung dari konteksnya.Dalam nas ini artinya adalah: 'kehilangan keselamatan kekal di dalam/bersama Kristus', 'untuk selamanya dibuang dari hadirat Kristus'. Dari segi kosa kata Yunani, keduanya mungkin. Ada dua hal (a) kesejajaran nast ini dengan Keluaran 32:31; (b) dalam Perjanjian Baru kata eukhesthai biasanya dipakai dengan arti "berdoa" (2 Kor. 13:7, 9; Kis. 26:

${ }^{6}$ Ola Tuluan, Introduksi PB (Batu: Departemen Literatur YPPII, 1999), 125.

${ }^{7}$ Utley, Kumpulan Komentar Panduan, 182.

${ }^{8}$ Ibid, 179

${ }^{9}$ Ibid.

${ }^{10}$ Ibid.
29; 27:29; Yak. 5:16) ${ }^{11}$ Ia bersedia kehilangan keselamatan bersama Kristus demi saudara saudaraku, karena melihat murka Allah kepada bangsa pilihan ini. ${ }^{12}$ Sama seperti dalam bahasa Indonesia, perkataan 'saudara 'adelphos menunjukkan hubungan darah: tetapi dalam Alkitab di samping itu 'saudara' adalah sesama anggota umat Allah, yakni Israel atau Gereja, ditambahkannya: "kaum sebangsaku secara jasmani" (harfiah: menurut daging). ${ }^{13}$

Rententan dari frasa kata benda (ayat 4-5) ini menyatakan dalam penggambaran yang rinci mengenai hak istimewa Israel, khususnya hubungan mereka dengan Allah, sebab mereka adalah orang Israel. ${ }^{14}$ Pada bagian ini Paulus ingin memberikan jawaban, dengan cara pemaparan tentang perasaan dirinya, akan kedudukan Israel sebagai umat pilihan. "Orang Israel" Ini adalah nama perjanjian dari Perjanjian Lama bagi benih Abrahan. Nama Yakub setelah suatu pergumulan yang sangat menentukan dengan Allah digantikan dengan Israel (Kej 32:28). Ini menjadi gelar bersama bagi bangsa Yahudi. Secara etimologi bisa jadi "kiranya $E l$ (Allah) bertekun" dan artinya, bukan kelicikan Yakub. "Mereka telah diangkat sebagai anak." 15 Dalam Perjanjian Lama bentuk Jamak dari "anak" biasanya berhubungan dengan para malaikat (Ayb. 1:6; 2:1; 38:7; Dan. 3:25; Mzm. 29:1; 89:6-7), sementara bentuk tunggalnya menunjuk pada: (1) Raja Israel (II Sam. 7:14); (2) Bangsa (Kel. 4:22,23; Ul. 14:1; Hos. 11:1); (3) Mesias (Mzm. 2:7); (4) Dapat menunjuk pada manusia (lih. Ul. 32:5; Mzm. 73:15; Yeh. 2:1; Hos. 1:10. Kej. 6:2 mendua; bisa manusia atau bukan). ${ }^{16}$ Dalam Perjanjian Baru kata ini menunjuk pada seseorang yang menjadi anggota keluarga Allah, ${ }^{17}$ (Rm. 8:15; 23). Israel telah diangkat men-

\footnotetext{
${ }^{11}$ End, Tafsiran Surat Roma, 483

${ }^{12}$ R.A Jaffray, Tafsiran Surat Roma (Makassar: Kalam Hidup, 1964), 118

${ }^{13}$ Ibid, 484

${ }^{14}$ Henry, Tafsiran Surat Roma, 229.

${ }^{15}$ Utley, Kumpulan Komentar Panduan, 182.

${ }^{16}$ Ibid, 182.

${ }^{17}$ Ibid, 182.
} 
jadi anak, yang secara harafiah: mereka mempunyai pengangkatan sebagai anak. ${ }^{18}$ Pengangkatan sebagai anak ditemukan dalam Keluaran 4:22, Yeremia 31:9, dan Hosea 11:1. Pengangkatan penggambaran utama Paulus bagi keselamatan adalah "adopsi", sementara dari Petrus dan Yohanes adalah "lahir baru". Kedua hal ini adalah penggambaan kekeluargaan. Israel menikmati pula kehadiran Tuhan secara kelihatan yang disebut "Kemuliaan"19 Akar kata Ibraninya berarti "berbobot" yang adalah suatu penggambaran bagi sesuatu yang berharga. Di sini hal ini menunjuk pada: (1) Penunjukan Diri Allah di gunung Sinai (Kel. 19:18-19); atau (2) tiang awan kemuliaan Shekinah yang memimpin bangsa Israel selama periode perjalanan di padang belantara (Kel. 40:3438). YHWH secara unik menyatakan diri-Nya pada Israel. Hadirat YHWH dinyatakan sebagai kemuliaan-Nya (I Raj. 8:10-11; Yeh. 1:28). Israel juga menerima "Perjanjian" (berith). Perjanjian adalah suatu cara yang digunakan oleh Allah yang benar dalam menghadapi manusia ciptaan-Nya. Beberapa perjanjian didasarkan atas sifat-sifat, tindakan-tindakan, dan maksud-maksud Allah. (1) Penciptaan itu sendiri (Kej. 1-2); (2) Panggilan Abraham (Kej. 12); (3) Perjanjian dengan Abraham (Kej. 15); (4) Pemeliharaan dan perjanjian kepada Nuh (Kejadian 6-9). ${ }^{20}$ Sifat mendasar dari perjanjian menuntut adanya suatu tanggapan atau iman: (1) Oleh iman Adam harus mentaati Allah dan tidak memakan buah dari pohon di tengah-tengah taman Eden (Kej. 2); (2) Oleh iman Abraham harus meninggalkan keluarganya, mengikuti Allah, dan percaya akan keturunan yang akan datang (Kej. 12,15); (3) Oleh iman, Nuh harus membangun bahtera jauh dari air dan mengumpulkan binatang-binatang (Kej. 6-9); (4) Oleh iman Musa membawa bangsa Israel keluar dari Mesir dan menerima petunjuk khusus bagi kehidupan sosial dan keagamaan dengan janji berkat dan kutuk (Ul.

${ }^{18}$ W.A. Criswell, Tafsiran Alkitab Surat Roma (Jakarta: BPK Gunung Mulia, 1992), 488.

${ }^{19}$ Ibid, 489.

${ }^{20}$ Utley, Kumpulan Komentar Panduan, 183.
27-28). Sasaran keduanya sama: (1) pemulihan persekutuan yang hilang dalam Kejadian dan (2) penetapan orang-orang benar yang mencerminkan sifatsifat Allah.

"Pemberian Hukum Taurat" dan Ibadah", hal ini akan menunjuk pada (1) penerimaan Musa akan Hukum di gunung Sinai (Kel. 19-20) dan pembangunan ibadah Bait Allah oleh Daud, atau (2) kemungkinan Kemah Musa di masa Perjalanan di padang belantara (Kel. 25-40).

"Janji-janji", sejak "perjanjian" disebutkan terdahulu, "janji” mungkin menunjuk pada Mesias (ay 5, misal Kej. 3:15; 49:10; Ul. 18:15,18-19; II Sam. 7; Mik. 5:2-5a; Zak. 2:6-13; 6:12-13; 9:9; 11:12). Janji-janji ini (perjanjian) mencakup baik bersyarat dan tidak bersyarat. Tidak bersyarat sejauh prestasi Allah (lih. Kej. 15:12-21), namun bersyarat pada iman dan ketaatan manusia (Kej. 15:6 dan Rm. 4). Hanya Israellah yang mem-punyai pewahyuan dari diri-Nya pribadi sebelum kedatangan Kristus.

"Bapa-bapa", ini berhubungan dengan Abraham, Ishak, dan Yakub, kepala-kepala keluarga dalam Kejadian 12-50 (Rm. 11:28; Ul. 7:8; 10:15) "yang menurunkan Mesias ${ }^{21}$ dalam keadaan-Nya sebagai manusia" ini dihubungkan dengan silsilah jasmani Mesias (1:3), Yang Diurapi, hamba pilihan khusus Allah yang akan menggenapi janji-janji dan rencana Allah, 10:6).

Istilah "Kristus" adalah terjemahan bahasa Yunani dari kata Ibrani "Yang Diurapi". Paulus tidak sering menggunakan kata Theos untuk Yesus, namun ia memakainya (Kis. 20:28; Ti. 2:13; Fil. 2:6). Frasa yang indah ini menunjukkan ketinggian dari kebodohan Israel dalam penolakkannya terhadap Yesus dari Nazareth.

"Selama-lamanya", secara harafiah merupakan frasa istilah Yunani "kepada segala jaman" (Luk. 1:33; Rm. 1:25; 11:36; Gal. 1:5; I Tim. 1:17). Ini adalah satu dari beberapa frasa yang berkaitan

${ }^{21}$ K.H, Toto Tasmara, Yahudi Mengapa Mereka Berprestasi (Jakarta: Publising Sinergi, 2010), 111 
(1) "keakhir jaman" (Mat. 21:19; Mrk. 11:14; Luk. 1:55; Yoh. 6:5,58; 8:35; 12:34; 13:8; 14:16; II Kor. 9:9) atau (2) "dari jaman dari jaman" (lih. Ef. 3:21). Tampaknya tidak ada perbedaan yang menyolok antara istilah-istilah "selamanya" ini.

\section{Dahulu Allah Sudah Memilih Siapa Yang Akan Menjadi Umat-Nya (Pasal 9:6-13)}

Firman Allah dalam konteks ini, frasa ini menunjuk pada janji-janji perjanjian dari Perjanjian Lama. Janji Allah adalah pasti (Bil. 23:19; Yes. 40:8; 55:11; 59:21). Dalam bahasa aslinya "(telah) gagal", atau "tidak ada pengaruhnya", evkpi,ptw ekpipto. Kata ini (ekpiptō) digunakan dalam Septuaginta beberapa kali untuk sesuatu (Yes. 6:13) atau seseorang (Yes. 14:12) yang jatuh.Janji Allah adalah pasti (lih. Bil. 23:19; Yes. 40:8; 55:11; 59:21). Bentuknya menjelaskan suatu kondisi suatu keberadaan dengan hasil yang abadi (hanya dinegatifkan). ${ }^{22}$ Terjemahan yang lebih mendekati 'mengatakan bahwa bukan janji Allah sudah tidak berlaku lagi' bukanya firman Allah seolah-olah gagal. ${ }^{23} \mathrm{Hal}$ ini bisa dilihat dengan tujuan Paulus kepada orang Yahudi di Roma. Paulus menegaskan bahwa Firman Allah, bukannya tidak berlaku lagi. Paulus juga melanjutkan dengan bukti-buktinya tentang pemilihan. Paulus memberikan jawab dengan memaparkan tentang sejarah orang Yahudi dari Perjanjian Lama. Arti dari pernyataan yang bersifat paradoks ini berkisar antara beberapa arti dengan menjelaskan bukti bahwa tidak semua orang dari Israel adalah orang Israel. ${ }^{24}(1)$ Israel, yang berarti keturunan Yakub (Kej. 32:2232); (2) Israel, yang berarti umat pilihan Allah; atau (3) Israel rohani, Israel yang artinya gereja, (Gal. 6:16; I Pet. 2:8,9; Why. 1:6) lawan dari Israel jasmani (ay 3-6). Hanya beberapa dari anak-anak Abraham adalah anak-anak perjanjian (ay 7). Bahkan orang Yahudi tidak pernah benar dengan Allah hanya berdasarkan garis keturunan mereka semata (ay

\footnotetext{
${ }^{22}$ Utley, Kumpulan Komentar Panduan, 186.

${ }^{23}$ End, Tafsiran Surat Roma, 425.

${ }^{24}$ Ibid
}

7), namun harus berdasarkan iman mereka (2:28-29; 4:1; Yoh. 8:31-59; Gal. 3:7-9; 4:23). Hanyalah sisasisa Israel yang menerima perjanjian Allah dan berjalan di dalamnya oleh iman $(9: 27 ; 11: 5)$.

Bagian kedua dari (ayat 7) adalah sebuah kutipan dari (Kej. 21:12d). Tidak semua anak-anak Abraham adalah anak-anak ikatan perjanjian Allah (Kej. 12:1-3; 15:1-11; 17:1-21; 18:1-15; Gal. 4:23). Terjemahan harafiah: "dan tidak juga sebab mereka keturunan Abraham mereka semua adalah anakanak, sebaliknya, dengan nama Ishak keturunanmu akan disebut "En Isaak klethesetai merupakan terjemahan kata-kata Ibrani nigra, disebut dengan (melalui) nama". Ini menunjukkan perbedaan antara Ismael dan Ishak dalam (ayat 8-9), dan Yakub dan Esau dalam (ayat 10-11). Dimana pemilihan Allah itu jatuh kepada Ishak anak yang lahir dari Sara bukan Hagar. Bahkan Paulus memberikan penegasan tentang pemilihan Allah adalah keturunan Ishak, 'keturunan' kale,w kaleo yang berarti lebih kepada satu asal, yaitu Ishak. Bahwa hal ini menujuk kepada hak preogatif Allah untuk pemilihan, yang dikehendaki Allah. Pada ayat ini Paulus ingin menekankan tentang perbedaan 'keturunan' (sperma $=$ 'benih' $)^{25}$ hal ini juga menujukan lingkungan luas semua orang yang lahir dari Abraham, tetapi pada bagian ayat selanjutnya tentang (sperma) hal itu berbicara tentang keturunan Abraham dalam lingkup kecil atau lingkup yang terbatas, dimana contoh itu diambil dari Ishak dan Ismael dan tentang pemilihan Allah.

Pemaparan sejarah tentang pemilihan Ishak dan Ismael, bahwa bukan anak yang dilahirkan dari daging adalah anak-anak Allah tetapi anak-anak yang telah diperjanjian. "Menurut daging" di sini bukan kata sarka, melainkan tes sarkos, "dari daging' (genetif). "Anak-anak perjanjian” dapat dipahami berdasarkan pengertian "anak" dalam bahasa Ibrani: mereka yang termasuk lingkungan perjanjian (bdk. 8:14). Terjemahan harafiah: "tetapi anak-anak perjanjian yang diperhitungkan dihormati/perhitung-

\footnotetext{
${ }^{25}$ End, Tafsiran Surat Roma, 428.
} 
kan sebagai keturunan". ${ }^{26}$ Mengenai "memperhitungkan", Yunani "logizesthai" (bdk. 4:3). Bentuk pasif orang ketiga menunjuk kepada Allah sebagai subyeknya (passivum divinum, bdk. 1:1b). ${ }^{27}$ Paulus sedang menggunakan istilah "daging" untuk menunjuk kepada nenek moyang bangsa (1:3; 4:1; 9:3, 5). Ia sedang mengkontraskan keturunan jasmani Abraham/ orang Yahudi (9:3) dengan anak-anak rohani (anak-anak perjanjian) dari Abraham (mereka yang akan mempercayakan diri pada Mesias yang dijanjikan Allah oleh iman). Tidak semua orang keturunan Abraham, yang lahir darinya secara alamiah, adalah anak-anak Allah, artinya termasuk lingkungan perjanjian (umat) Allah. Yang termasuk lingkungan perjanjian itu ialah mereka yang dipilih Allah, dengan pemilihan yang sama sekali bebas. ${ }^{28}$ Ini bukan kontras yang sama dengan (8:4-11), manusia yang jatuh sebagai lawan dari manusia tebusan. Penegasan Paulus bahwa kaum perjanjian yang taat akan menerima janji Allah. Ismael lahir dari keinginan manusia, sedangkan Ishak dari Allah begitu juga dengan pemilihan dan penerima janji. Hanyalah anak-anak janji dihormati [seperti] keturunan. Kasus genitive dimana janji kepemilikan adalah kaum perjanjian, bukan keturunan yang di tekankan oleh kaum Yahudi. Paulus juga meneruskan dengan sejarah Israel, bagaimana Allah menyatakan kepada bangsa Israel bagaimana nenek moyang mereka Abraham. Dalam ayat 7-8 peristilahan bergantiganti. Dalam (ayat 7a) "keturunan" (sperma = benih) menunjukkan lingkungan luas semua orang yang lahir dari Abraham, ${ }^{29}$ sedangkan dalam (ayat $7 \mathrm{~b}$ dan 8) yang disebut "keturunan" (sperma) ialah lingkungan terbatas orang-orang pilihan.

Anak perjanjian ("benih") akan berasal dari Sarah atas inisiatif Allah. ${ }^{30}$ Terjemahan harafiahnya:

${ }^{26}$ William Barclay, Surat Roma Pemahaman Alkitab Sehari-Hari (Jakarta: BPK Gunug Mulia, 2003), 193.

\footnotetext{
${ }^{27}$ End, Tafsiran Surat Roma, 497.

${ }^{28}$ Ibid, 497.

${ }^{29}$ End, Tafsiran Surat Roma, 499.

${ }^{30}$ Utley, Kumpulan Komentar, 186.
}

"sebab (firman) janjilah (genetif) firman ini". Ada dua tafsiran mengenai ayat ini: (a) Ada ahli menganggap tekanan berada di atas "ini", (b) Yang lain beranggapan, karena ditempatkan pada awal kalimat maka epanggelias/janji yang ditekankan, sehingga terjemahannya, "Sebab firman ini adalah/bersifat (firman) janji (demikian, secara bebas LAI). ${ }^{31}$ Ishak adalah penggenapan khusus dari janji Allah kepada Abraham dalam (Kej. 12:1-3) tiga belas tahun sebelumnya. Firman Allah itu memilik janji tentang Sara akan melahirkan, (Kej.17:21). Dimana ketika Malaikat Allah memberikan janji kepada Sara akan kelahiranya. Bahwa ketika mereka akan datang untuk kedua kalinya pada saat itulah Sara akan megandung dan melahirkan seorang anak laki-laki 'dalam arti menerima janji'.

Perjanjian Allah masih diteruskan yaitu pernikahan Ishak dan Ribka. Dimana bangsa Israel tahu janji Allah melalui leluhur mereka, yaitu Ishak, dari keturunan Ishak inilah terbentuklah bangsa Israel. Ini diungkapkan dengan kata lebih terang lagi koi,th koite (mengandung; ngerti). Bahwa mereka tahu tentang keberadaan mereka sebagai orang Israel/ Yahudi. Istri-istri dari Abraham, Ishak, dan Yakub adalah mandul; mereka tidak bisa mengandung. Ketidakmampuan mereka untuk mendapat anak ialah satu dari cara Allah untuk menunjukkan bahwa Ia berkuasa atas perjanjian-perjanjian-Nya, yaitu garis turunan Mesias. Cara yang lain adalah bahwa garis keturunan Mesias yang benar tidak pernah dihasilkan melalui anak sulung dari kepala-kepala keluarga (yang secara budaya seharusnya demikian). Kuncinya ialah Pilihan Allah (ay 11-12). Kedua ayat ini adalah satu kalimat dalam bahasa Yunani. Keterangan ini diambil dari (Kej 25:19-34). Contoh ini digunakan untuk membuktikan pilihan Allah (ay 16), bukan (1) keturunan manusia atau (2) kemampuan atau prestasi manusia (ay 16). Ini adalah inti dari Injil, perjanjianbaru (Yer. 31:31-34; Yeh. 36:2236). Ayat 11 dan 12 adalah penegasan Paulus ten-

\footnotetext{
${ }^{31}$ End, Tafsiran Surat Roma, 499.
} 
tang doktrin pemilihan, dari Allah tanpa campur tangan manusia. Paulus menjelaskan tentang firman Allah kepada Ribka "anak yang tua akan menjadi hamba bagi yang muda 'Ikatan perjanjian Allah jatuh kepada anak yang muda, yaitu Yakub. Dalam hal ini, haruslah diingat bahwa pilihanAllah tidak dimaksudkan untuk menyingkirkan, namun untuk mencakup Mesias akan datang dari benih yang terpilih, namun Ia akan datang bagi semua (yang melakukan iman, lih. 2:28-29; 4:3,22-25; pasal 10). "Rencana" ini adalah kata mejemuk pro ditambah tithèmi, yang mengandung beberapa pengertian: (1) Dalam (Rm. 3:25): a) ditetapkan secara terbuka di masyarakat, (b) anugerah perdamaian; (2) Merencanakan lebih dahulu: a) Paulus (Rm. 1:13), (b) Allah (Ef1:9). Bentuk kata bendanya (prothesis), yang digunakan dalam naskah ini berarti menetapkan sebelumnya". Paulus memakai beberapa kata majemuk dengan kata depan pro (sebelum) dalam (Rm. 8) dan (Ef. 1). ${ }^{32}$

1. proginōskō (mengetahui sebelumnya), Roma 8:29

2. proorizō (dirancang sebelumnya), Roma 8:29; Efesus $1: 5,11 ; 30 ; 1: 9$.

3. prothesis (maksud yang telah ditetapkan sebelumnya) Roma 9:11

4. proetoimazō (ditunjukkan sebelumnya), Roma 9:23

5. prolegō (dikatakan sebelumnya), Roma 9:29

6. proelpizō (diharapkan sebelumnya), Efesus $1: 12$

Paulus mengutip nubuatan dari (Kej. 25:23), pada ayat (12) berkenaan dengan Esau dan Yakub. Ini menunjukkan bahwa Ribka dan Yakub melaksanakan nubuatan, bukan untuk kepentingan pribadi, dalam mengelabui Ishak dalam kaitannya dengan berkat. Kata "tapi (Aku) membenci Esau" dalam (ayat 13) adalah kutipan dari (Mal. 1:2-3). "Benci” adalah sebuah istilah Ibrani untuk perbandingan. Ayat ini menjadi penegasan yang sangat komplek tentang pemilihan Allah. Dimana Allah mengasihi Yakub.

\footnotetext{
${ }^{32}$ Utley, Kumpulan Komentar Panduan, 187.
}

Paulus terus menekankan bahwa pemilihan Allah tidak dilihat dari perbuatan objek pilihan dan tidak tergantung objek, tetapi pemilihan Allah itu. Didasarkan atas kasih Allah kepada pilihanya atau kepada objeknya. Alasanya pemilihan ini karena pemilihan Allah atas Israel tidak tergantung pada perbuatan manusia dan tidak tegantung pada mereka yang tidak taat hal itu tidak dapat meniadakan tujuan-tujuan Allah yang didasarkan atas pilihan Allah. ${ }^{33}$ Istilah-istilah kemanusiaan seperti "cinta" dan "benci" tidak berhubungan dengan perasaan Allah kepada orang-orang tersebut, namun komitmen-Nya pada garis Mesias dan perjanjian-Nya. Yakub adalah anak nubutan berdasarkan dari (Kej. 25:23), Esau di dalam (Mal. 1:2-3) dikaitkan pada bangsa Edom (yaitu keturunan Esau).

\section{Penolakan Israel Akan Keadilan Allah (Pasal 9:14-18)}

Tekanan kunci dari konteks (ayat 14) ini adalah bahwa Allah bisa berbuat apa saja kepada manusia (manusia pemberontak), namun demikian, kedaulatan Allah dinyatakan dalam kemurahan (ay 15), bukan kekuasaan semata-mata. Bila diadili sesuai perbuatan, maka tidak ada yang layak dipilih. ${ }^{34}$ Harus juga dinyatakan bahwa pilihan kedaulatan Allah tidak didasarkan atas pengetahuan dini akan pilihan-pilihan dan tindakan yang akan diambil oleh manusia di masa yang akan datang. Jika seandainya pemilihan itu didasarkan atau pengetahuan dini tersebut, maka ini berarti bahwa akhirnya pilihan dan tindakan manusialah yang menjadi dasar pemilihan Allah (ay 16; 1 Pet. 1:2). Dibalik ini semua terletak pandangan Yahudi tradisional mengenai kemakmuran orang benar (Ul. 27-28; Ayb. dan Mzm. 73). Namun, Allah memilih untuk memberkati orang yang tidak layak melalui imannya (bukan atas dasar prestasinya (5:8). Allah mengetahui segala perkara namun Ia memilih untuk membatasi pilihan-Nya (1)

\footnotetext{
${ }^{33}$ Warren W. Wiersbe, Benar di Dalam Kristus (Bandung: Kalam Hidup, 1996), 102

${ }^{34}$ Ibid.
} 
dalam kemurahan dan (2) dalam janji.Tanggapan manusia harus ada, namun ini mengikuti dan akhirnya meneguhkan pilhan Allah yang mengubahkan kehidupan. Atas kedaulatan Allah yang telah memilih siapa yang dipilih hal itu dapat memaksa kita menarik kesimpulan bahwa Allah 'tidak adil'. Paulus telah mengatakan bahwa pemilihan Allah tidak terikat pada suatu garis keturunan, bahwa Allah bebas memilih sebagian keturunan Abraham dan menolak sebagiannya yang lain. Pihak Yahudi merasa kedudukannya sebagai umat Allah terancam oleh kebebasan seperti itu. Karena itu tanggapannya tajam sekali: Orang Yahudi menganggap Allah yang digambarkan itu adalah Allah yang tidak adil. Artinya: Allah yang sewenang-wenang, yang tidak dapat diandalkan, yang tidak setia. "Apakah Allah tidak adil?" Bagaimana Allah menyuruh manusia bertanggung jawab bila faktor dasar keputusannya adalah kedaulatan Allah (ay 19)? Inilah misteri dari pemilihan. Kata "Mustahil" adalah suatu bentuk optative yang langka namun sering digunakan Paulus untuk sebuah penegatifan ketegasan yang biasanya terhadap pertanyaan penentang diatribenya $(3: 4,6,31$; $6: 2,15 ; 7: 7,13 ; 11: 1,11 ; 1$ Kor. $6: 15$; Gal. 2:17; 3:21; $6: 14)$.

Pernyataan selanjutnya pada (ayat 15) adalah sebuah kutipan dari Keluaran 33:19 untuk menegaskan konsep pemilihan Allah sejak waktu Israel dibebaskan dari Mesir. Dalam hal ini ada konsep yang perlu dipahami yaitu: Allah bebas dan berdaulat dalam kemurahan-Nya. Allah bebas bertindak menurut rencana-rencana penebusan-Nya sendiri. Bahkan Musa tidak berlayak untuk berkat Allah (Kel. 33:20). Ia adalah seorang pembunuh (Kel. 2:11-15). Kuncinya ialah bahwa pilihan-Nya adalah di dalam kemurahan (ayat 16, 18-23; 11:30,31.32). "kemurahan hati" Kata Yunani ini (eleos, ayat 15, $16,18,23 ; 11: 30,31,32$ ) digunakan dalam Septuaginta (LXX) untuk menterjemahkan istilah Ibrani yang khusus hesed, yang artinya "setia loyal pada perjanjian." Kasih kemurahan dan pilihan Allah adalah jamak, berkelompok, (Yahudi [Ishak], bukan
Arab [Ismael]; Israel [Yakub], bukan Edom [Esau], namun orang Yahudi yang percaya dan orang bukan Yahudi yang percaya) sebagaimana juga semua orang. Kebenaran ini adalah salah satu kunci untuk membuka misteri dari doktrin pradestinasi (penebusan universal). Kunci lain dalam konteks pasal 911 adalah sifat Allah yang tak pernah berubah kemurahan $(9: 15,16,18,23 ; 1: 30,31,32)$, dan bukan prestasi manusia. Kemurahan melalui pemilihan pada waktunya akan mencapai semua yang percaya kepada Kristus. Satu orang membuka pintu iman kepada semua (5:18-19).

Kutipan universal yang kuat dari (Kel. 9:16; ayat 17-18) adalah kesimpulan yang ditarik dari kutipan tersebut. Firaun dikatakan telah mengeraskan hatinya dalam (Kel. 8:15,32; 9:34). Allah dikatakan telah mengeraskan hati-Nya dalam (Kel. 4:21; 7:3; 9:12; 10:20, 27; 11:10). Contoh inidigunakan untuk menunjukkan kedaulatan Allah (ay 18). Firaun harus bertanggungjawab atas pilihannya. Allah menggunakan keangkuhan, kekeras kepalaan pribadi Firaun untuk mencapai kehendak-Nya bagi Israel (ayat 18). ${ }^{35}$ Juga perhatikan maksud tindakan Allah dengan Firaun adalah penebusan dan lingkupnya mencakup semua. Semua ini dimaksudkan: (1) untuk menunjukkan kuasa Allah (sebagai lawan dari dewadewa alam dan binatang dari Mesir, sebagaimana yang diperbuat Kejadian 1 terhadap dewa perbintangan Babilonia); (2) untuk menunjukkan Allah kepada Mesir dan dengan cara sama, seluruh dunia (ay 17). ${ }^{36}$ Dalam konteks ini hak dari satu orang berkurang demi kebutuhan keseluruhan. Contoh dalam Perjanjian Lama mengenai: (1) Anak-anak Ayub yang pertama yang mati karena Allah mengijinkan setan mencobai Ayub (lih. Ayb 1-2); (2) Tentara Israel yang mati akibat dosa Akhan (Yos. 7); (3) Anak sulung Daud dengan Betsyeba yang mati karena dosa Daud (lih. II Sam 12:15). Kita semua dipengaruhi oleh pilihan dari orang lain. ${ }^{37}$ Kebersa-

\footnotetext{
${ }^{35}$ End, Tafsiran Surat Roma, 499.

${ }^{36}$ Utley, Kumpulan Komentar Panduan, 189.

${ }^{37}$ Ibid, 189.
} 
maan ini dapat dilihat di PB dalam (Rm. 5:12-21). Kisah Firaun (sebagaimana juga kisah Yakub dan Esau dalan ayat 10-13) di sini menjadi perumpamaan. Yang diumpamakan ialah nasib Israel, atau lebih tepat: perbuatan Tuhan terhadap bangsa Israel pada zaman Paulus sendiri. Kisah Firaun dalam Keluaran pasal 5-9 mengilustrasikan kebenaran ini. Bahwa pada mulanya pemberontakan Firaun berasal dari dirinya sendiri (Kel. 5:2), dan karena Firaun mengeraskan hatinya sendiri (Kel.7:13,22; 8:15, 19,32), maka akhirnya, setelah 6 malapetaka supranatural, Allah mengeraskan hati Firaun (Kel. 9:12). ${ }^{38}$

\section{Kedaulatan Allah Dalam Menentukan Pilihan- Nya (Pasal 9:19-26)}

Pernyataan Paulus dalam ayat 19 "yang menentang kehendak-Nya" Ini adalah sebuah perfect active indicative, yang menekankan suatu fakta yang ada dengan hasil yang berkelanjutan (II Taw. 20:6; Ayb. 9:12; Mzm. 135:6; Dan. 4:35). Diatribenya berlanjut. Secara logika, mengikuti diatribe Paulus adalah cara terbaik untuk bisa menggaris besarkan dan memahami pemikiran Paulus. Ayat 19 penegasan dari Paulus untuk kesesatan pikiran tentang keadilan dan pilihan Allah. Bagian yang kedua adalah pertanyan litorik dari Paulus kepada pola pemikiran mereka dengan kata 'sebab siapa yang menantang mereka?' Dari hal diatas Paulus ingin meruntuhkan, dasar pemikiran mereka tentang cara Allah yang salah. Kehendak Allah perlu dilihat pada dua tingkatan. Pertama adalah rencana penebusanNya bagi seluruh umat manusia yang telah jatuh (Kej. 3:15). Rencana ini tidak dipengaruhi oleh pilihan manusia. Namun pada tingkatan kedua, Allah memilih untuk menggunakan perantaraan manusia (Kel. 3:7-9, 10). Manusia dipilih untuk menggenapi rencana-Nya (baik secara positif Musa, secara negatif Firaun).

Gambaran ini dalam ayat 20-21 diambil dari Yesaya 29:16; 45:9-13; 64:8; Yeremia 18:1-12.

\footnotetext{
${ }^{38}$ End, Tafsiran Surat Roma, 449.
}

Penggambaran dari YHWH sebagai tukang periuk sering digunakan untuk Allah sebagai pencipta, sementara manusia berasal dari tanah liat (Kej. 2:7). Paulus membawa pulang pokok pikirannya mengenai kedaulatan dari sang pencipta dengan menggunakan tiga pertanyaan lagi - dua yang pertama ada di ayat 20 dan yang ketiga ada di ayat 21 . Pertanyaan terakhir mengembalikan pada analogi mengenai pilihan positif Allah dalam Musa dan pilihan negatif dalam Firaun. Kontras yang sama terlihat dalam (1) Ishak - Ismael, ayat 8-9; (2) Yakub Esau, dalam ayat 10-12; (3) bangsa Israel dan bangsa Edom dalam ay 13. Analogi yang sama ini dikembangkan untuk mencerminkan situasi di jaman Paulus mengenai orang Yahudi yang percaya dan tidak percaya. ${ }^{39}$ Pilihan positif Allah akhirnya dinyatakan dalam pencakupan akan orang bukan Yahudi yang percaya (ayat 24-29, dan 30-33). Ayat 20 dan 21 ini Paulus ingin mengantisipasi pembaca terhadap padangan ketidakadilan Allah. Dengan kata-kata yang mengingatkan kepada sejarah Ayub, (Ayb. 9: 12, 40:2) Ia mempertanyakan Apakah kita pantas mengajukan pertanyan semacam itu, (Rm. 9:20), ${ }^{40}$ kemudian ia kembali dengan mengutif perkataan Yesaya 29:16, 45:9. Dapatkah yang dibentuk berkata kepada yang membentuknya mengapakah Engkau membentuk kami demikian (20-21). ${ }^{41}$ Ilustrasi tentang tukang 'periuk ini pernah dipergunakan dengan sangat berhasil oleh Yeremia beberapa abad sebelumnya (Yer. 18:4-6). Paulus menekankan kekuasaan sepenuhnya dari tukang periuk atas tanah liat untuk dibentuk sesuai dengan kehendak tukang periuk. Sebuah benda itu dihormati atau tidak tergantung pada kegunaan yang ditetapkan untuk benda tersebut.

Paulus menyatakan sifat penebusan Allah dalam (ayat 22). Allah ialah Allah dari keadilan. Ia akan menuntut pertanggung jawaban manusia atas perbuatan mereka. Tetapi Ia juga adalah Allah yang

\footnotetext{
${ }^{39}$ Utley, Kumpulan Komentar Panduan, 190

${ }^{40}$ Henry, Tafsiran Surat Roma, 244.

${ }^{41}$ Wiersbe, Benar di Dalam Kristus, 104-105.
} 
berkemurahan. ${ }^{42}$ Semua manusia layak untuk mati (1:18-3:21). Pengadilan bukanlah kabar yang baik. Sifat Allah yang terutama adalah kemurahan dan bukan kemurkaan (Ul. 5:9-10; 7:9; Hos. 11:8-9). Pilihan-Nya adalah untuk penebusan (Yeh. 36:2233). Ia bersabar terhadap manusia berdosa (Yeh. 18). Ia bahkan menggunakan kejahatan bagi rencana penebusan-Nya (contoh: Setan, Firaun, Penenung dari En-Dor, Asyur, Nebukadnezar, Koresh, dan dalam (pasal 11), orang Israel yang tidak percaya. Allah mempertunjukkan murka-Nya untuk memberitakan kuasa-Nya (ayat 22) dan kekayaan kemuliaanNya (ayat 23). Tindakan Allah selalu memiliki maksud penebusan (kecuali Gehenna, yang adalah penyingkiran terakhir dari para pembangkang yang tidak percaya dan dosa).

"Benda-benda kemurkaan" istilah ini melanjutkan penggambaran Paulus mengenai tanah liat dari ayat $20-21 .{ }^{43}$ Benda-benda ini dilukiskan sebagai disiapkan katartizountuk kebinasaan. ${ }^{44}$ Allah secara khusus dikaitkan dengan soal mempersiapkan sebelumnya (bentuk aktif) benda-benda belas kasihan. Tetapi apabila mengenai benda-benda kemurkaan orang yang belajar Alkitab melihat bentuk pasif yang tidak terbatas. Apakah yang mempengaruhi manusia sehingga ia berada dalam keadaan disiapkan untuk kebinasaan abadi? Jawabnya kompleks. Termasuk di dalamnya adalah tindakan-tindakan penuh dosa serta sifat memberontaknya. Tercakup juga lingkungan hidupnya yang menjadikan dosa itu sesuatu yang menarik serta hukuman Allah (bdg. Rm. 1:24,26,28). Faktor-faktor ini mempengaruhi benda-benda tertentu sehingga menjadi benda-benda kemurkaan, yaitu objek-objek yang berada dalam keadaan dipersiapkan untuk kebinasaan. Allah secara khusus mempersiapkan sebelumnya benda-benda belas kasihan untuk kemuliaan, dan Dia juga menya-

\footnotetext{
${ }^{42}$ Dave Hagelberg, Tafsiran Roma dari Bahasa Yunani (Bandung: Kalam Hidup, 2000), 191

${ }^{43}$ Mafred T. Brauch, Ucapan Paulus Yang Sulit (Malang: Seminari Alkitab Asia Tenggara, 2003), 191

${ }^{44}$ G. Raymond Carlson, Surat Roma (Malang: Gandum Mas, 1878), 88
}

takan kepada mereka kekayaan kemuliaan-Nya. Kemuliaan mengacu kepada sinar yang memancar dari diri Allah. Pencurahan kemurahan Allah berarti kekayaan yang tidak dapat dilukiskan oleh mereka yang menerimanya.Siapakah benda-benda belas kasihan ini? Secara jelas hal ini menunjuk pada manusia yang tidak percaya alat yang digunakan Allah untuk melaksanakan rencana penebusan-Nya. Benda-benda "yang telah dipersiapkan-Nya untuk kemuliaan" Kebenaran yang sama ini dinyatakan dalam Roma 8:29-30 dan Efesus 1:4,11. ${ }^{45}$ Pasal ini adalah pernyataan terkuat mengenai kedaulatan Allah dalam Perjanjian Baru. Tidak mungkin disangkal bahwa Allah berkuasa penuh terhadap penciptaan dan penebusan. Kebenaran yang agung ini tidak boleh dihaluskan atau di lunakkan. Namun demikian ini harus diseimbangkan dengan pilihan Allah akan perjanjian sebagai cara menghubungkan diri dengan manusia ciptaan-Nya, yang diciptakan sesuai dengan gambar-Nya. Pastilah benar bahwa beberapa perjanjian dalam Perjanjian Lama, seperti Kejadian 9:8-17 dan 15:12-21, adalah tidak bersyarat dan tidak berhubungan dengan semua tanggapan manusia, namun perjanjian-perjanjian lain mensyaratkan tanggapan manusia (yakni, Eden, Nuh, Musa, Daud). Allah punya rencana penebusan bagi ciptaanNya, tak seorang pun dapat mempengaruhi rencana ini. Allah telah memilih untuk mengijinkan pribadipribadi untuk berpartisipasi dalam rencana-Nya. Kesempatan berpartisipasi ini adalah ketegangan teologis antara kedaulatan (Rm. 9) dan kehendak bebas manusia (Rm. 10) tidaklah tepat untuk memilih satu tekanan alkitabiah dan mengabaikan yang lain. Ada ketegangan antar doktrin karena orang timur menyajikan kebenaran dalam suatu pasangan dialektis atau pasangan yang dipenuhi ketegangan. Doktrin harus dipegang dalam hubungannya dengan doktrin lain. Kebenaran adalah sebuah mosaik dari kebenaran-kebenaran. Paulus tidak menarik kesimpulan logis terhadap orang yang tidak percaya yang

\footnotetext{
${ }^{45}$ Utley, Kumpulan Komentar Panduan, 191.
} 
dipersiapkan (kataptizō) untuk kemurkaan (ay 22) dan orang-orang percaya yang dipersiapkan (proetoimazō) untuk kemuliaan (ay 23). ${ }^{46}$ Apakah pilihan Allah satu-satunya faktor atau apakah pilihan Allah didasarkan atas kemurahan bagi semua, namun beberapa orang menolak penawaran-Nya? Apakah manusia mempunyai bagian dalam penentuan masa depannya sendiri (9:30-10:21)? Konsep perjanjian mempersatukan keduanya dengan penekanan pada Allah. Manusia hanya bisa menanggapi inisiatif Allah, (mis. Yohanes 6:44,65). Sifat Allah tidaklah plin-plan, namun berkemurahan. Ia menjangkau semua manusia ciptaan yang sadar yang diciptakan menurut gambar-Nya (Kej 1:26,27).

Obyek janji Allah lebih lebar dari hanya bangsa Israel (ayat 24). Allah telah menunjukkan kemurahan bagi manusia berdasarkan pilihan-Nya dan keistimewaan dalam pemilihan Allah. ${ }^{47}$ Janji dari (Kej 3:15) berhubungan dengan semua manusia (karena belum ada orang Yahudi sampai pasal 12). Pemanggilan Abraham berhubungan dengan semua manusia (Kej. 12:3). Panggilan Israel sebagai kerajaan imamat berhubungan dengan semua manusia (Kel. 19:5-6). Inilah misteri dari Allah yang tersembunyi, namun sekarang telah dinyatakan sepenuhnya (Ef. 2:11-3:13; Gal. 3:28; Kol. 3:11). Penegasan Paulus dalam (ay 24) akan digambarkan dengan kutipan-kutipan Perjanjian Lama (ayat 25-29); (1) ayat 25, Hosea 2:23; (2) ayat 26, Hosea 1:10b; (3) ayat 27, Yesaya 10:22 dan/atau Hosea 1:10a; (4) ayat 28, Yesaya 10:23; (5) ayat 29, Yesaya 1:9.

Dalam konteks ayat 25-26, bagian ini berasal dari Septuaginta (LXX) dari Hosea 2:23 (dengan sedikit penyesuaian) dan 1:10, dimana ini dihubungkan dengan sepuluh suku di utara, namun di sini Paulus menunjuk pada orang bukan Yahudi. Hal ini pemakaian Perjanjian Lama yang lazim oleh para penulis Perjanjian Baru. Mereka melihat gereja sebagai penggenapan janji-janji kepada Israel (2 Kor.
6:16; Tit. 2:14; 1 Pet. 2:5-9). Dalam kasus ini bagian dalam Hosea menunjuk pada Israel yang tidak setia. Jika Allah dapat memulihkan sepuluh suku utara yang menyembah berhala, Paulus melihat ini sebagai bukti kasih dan pengampunan Allah yang satu hari nanti bahkan mencakup orang-orang kafir penyembah berhala. (Orang bukan Yahudi). Hal ini dikatakan tentang pemulihan akan umat dimana Allah memperbaharui pilihan-Nya. ${ }^{48}$

\section{Panjang Sabar Dan Kemurahan Allah Sebagai Penjunan (Pasal 9:27-29)}

Paulus memulai bagian ini dengan kutipan lepas dari Septuaginta (LXX) dari (Yes.10:22-23) pada ayat (27-28). Textus Receptus menambahkan frasa penutup dari (Yes. 10:23). Namun hal ini tidak terdapat dalam naskah-naskah kuno Yunani. Tetapi tentang pokok utama yang dikutip oleh Paulus di sini, naskah Ibraninya sesuai dengan LXX. Hanya sisa dari anak-anak Israel yang akan diselamatkan (LXX), (akan berbalik kembali, naskah Ibrani), yaitu, berbalik kepada Allah. Kata "sisa" sering digunakan dalam kitab nabi-nabi Perjanjian Lama untuk menunjuk pada orang-orang Israel yang ditawan, yang akan dibawa kembali oleh Allah ke tanah perjanjian. ${ }^{49}$ Konsep PL tentang "sisa-sisa yang setia" adalah tema berulang dari para nabi (kebanyakan nabi-nabi dari abad ke delapan dan Yeremia). Ini digunakan dalam tiga pengertian: (1) Mereka yang selamat dari penawanan (contoh, Yes. 10:2023; 17:4-6; 37:31-32; Yer. 42:15,19; 44:12,14,28; Am. 1:8); (2) Mereka yang tetap setia pada YHWH (contoh, Yes. 4:1-5; 11:11,16; 28:5; Yl. 2:32; Am. 5:14-15; Mik. 2:12-13; 4:6-7; 5:7-9; 7:18-20); (3) Mereka yang adalah bagian dari pembaruan dan penciptaan kembali eskatologis (contoh, Am. 9:1115). Dalam konteks ini Allah memilih hanya beberapa (mereka dengan semangat kesetiaan) dari sisasisa (yang selamat dari penawanan) untuk kembali

\footnotetext{
${ }^{46}$ Ibid.

${ }^{47}$ Carlson, Surat Roma, 90.
}

\author{
${ }^{48}$ Ibid, 192 \\ ${ }^{49}$ Utley, Kumpulan Komentar Panduan, 193.
}


ke Yudea. Sebagaimana telah kita saksikan sebelumnya dalam pasal ini, tema dari masa lalu Israel muncul kembali (ay 6). Allah mengurangi jumlahnya sehingga Ia bisa menunjukkan kuasa, ketetapan, dan perhatian-Nya (contoh, Gideon, Hak. 6-7). Dalam penggunaan Paulus, istilah ini menunjuk pada orang Yahudi yang memiliki hubungan iman dengan Allah dan/mereka yang telah mendengar Injil dan menanggapinya dengan iman pada Kristus. Bahkan dalam Israel perjanjian, terdapat suatu pemisahan rohani, hanya sebagian yang benar dengan Allah.

Pemilihan Israel tidak menyingkirkan kebutuhan akan tanggapan iman pribadi (Yes. 1:16-20). Paulus sedang menggunakan frasa Perjanjian Lama yang semula berhubungan dengan tawanan Yahudi, yang hanya sedikit dari mereka kembali ke Palestina, untuk menunjuk pada mereka yang telah mendengar Injil, namun sebagian besar dari mereka tidak percaya dan menerima Kristus. Hanya sebagian kecil dari pendengar (Yahudi dan Non Yahudi) di abad pertama menanggapi berita Injil. Paulus mengembangkan tema ini lebih lanjut di dalam (Rm. 11).

"Berseru" (krazei) yang punya arti ucapan yang diilhami roh nubuat (bdk. Rm. 8:15; Yoh. 1:15; 7:28; 12:44). "Sekalipun" (ean ei), adalah realistis, artinya menunjukkan keadaan yang memang berlaku.

"Jumlah anak Israel" merupakan penyesuaian naskah Yesaya dalam LXX dengan naskah (Hos. 1:10) yaitu kalimat yang mendahului kutipan dalam (ayat 26).

"Seperti pasir di laut", ini adalah bagian dari bahasa penggambaran mengenai banyaknya hasil dari janji Allah kepada Abraham (Kej. 15:5; 22:17; 26:4). ${ }^{50}$ Terdapat kesulitan dalam menafsirkan (ayat 28) karena ada perbedaan bahasa dan tekstual. Dua kemungkinan untuk menerjemahkan dan menafsirkan ayat ini "suntelon kai suntemnon" (sempurna dan segera): (1) Tuhan akan bertindak dengan me-

\footnotetext{
${ }^{50} \mathrm{Ibid}, 193$.
}

laksanakan firman-Nya dan dengan mempersingkat atau memotong. Kata mempersingkat dapat ditafsirkan sebagai memenuhi janji-janji sampai tingkat tertentu atau sebagai mengurangi bangsa itu menjadi suatu sisa; (2) Tuhan akan bertindak dengan mengakhiri dan mempersingkat (waktu). Ini berarti bahwa Allah tidak akan terus-menerus memperpanjang masa panjang sabar-Nya. tetapi bahwa penghakimanNya akan tiba.

Paulus mengutip (Yes.1:9) dari LXX, pada (ayat 29) yang menyebutkan "meninggalkan pada kita keturunan," (benih). Naskah Ibrani berbunyi. "meninggalkan sisa yang sangat sedikit." ${ }^{51}$ Kata "meninggalkan" (engkatelipen), yang sempurna dengan (hupoleimma), "sisa" dalam (ayat 27). Seandainya Allah tidak menyisakan sedikit, maka bangsa Israel pasti sudah musnah. Penghakiman Allah atas Israel selalu menyisakan: (1) Sisa-sisa orang yang percaya atau; (2) Garis keturunan Mesias. Allah menyisakan beberapa untuk menjangkau yang banyak.

"Sodom ...Gomora" (ayat 28) berhubungan dengan penghakiman Allah. Ayat ini khususnya menyebutkan dua kota kafir yang dimusnahkan Allah dalam Kejadian 19:24-26, namun ini menjadi suatu istilah bagi penghakiman Allah (Ul. 29:34; Yes. 13:19; Yer. 20:16; 49:18; 50:40; Am. 4:11). Paulus menekankan kembali tentang kasih Allah kepada orang Yahudi hal ini terlihat dari kutipan Paulus "Seandainya Tuhan semesta alam tidak meninggalkan pada kita keturunan," (Yes. 1:9). ${ }^{52}$ Paulus menjelaskan kembali tentang cerita murka Allah terhadap sodom dan Gomara (Kej. 19:28) yang diungkapkan oleh Yesaya, dimana semua hal musnah tidak ada yang tersisa. Penduduk asli sodom dan Gomora musnah tidak ada yang hidup untuk melanjutkan keturunan dari penduduk itu. Tetapi tidak dengan bangsa Yahudi dimana Allah tetap memberikan kepada umat pilihan kesempatan-kesempatan

\footnotetext{
${ }^{51}$ Ibid, 194.

${ }^{52}$ S. Van Der linder, Tafsiran Surat Roma
} (Bogor: BPK Gunung Mulia, 1966), 98. 
akan janji dan pemenuhan atas pilihan Allah kepada mereka.

\section{Kondisi Israel Saat Ini (Pasal 9:30-33)}

Paulus memberi suatu kesimpulan yang mengejutkan dari maksud pemilihan Allah. Ayat 3033 adalah satu kalimat yang dipisahkan de, yang mempertentangkan "bangsa-bangsa lain" dan "Israel". "Bangsa-bangsa lain" (Yunani: ethne) "orang-orang kafir" (bdk. Ayat 24). Paulus memakai istilah olahraga.

"Mengejar" (diokein) di sini sama artinya seperti 'usaha' dalam (ayat 16, bdk.Fil. 3:12,14). Kata kerja Yunani yang diterjemahkan 'beroleh' dipakai juga dalam 1 Korintus 9:24, Filipi 3:12, dan mengandung arti: memperoleh hadiah dalam pertandingan. Maka untuk memahami makna kedua ayat ini harus di bayangkan pertandingan olahraga berlari. Orang yang sama sekali tidak ikut bertanding mendapat hadiah. Sebaliknya, orang lain, yang telah berlaridinyatakan tidak ikut bertanding karena lari di jalur yang keliru, dan tidak tidak memperoleh hadiah. Israel telah berlari mengejar kebenaran. Mereka telah berupaya sekeras-kerasnya melakukan hukum Tuhan, agar dinyatakan benar.Meskipun demikian, mereka tidak memperoleh hadiah. Ayat 32a, menjelaskan alasan itu.Mereka salah menafsirkan hukum Taurat. Sebab mereka menyangka (hos) bahwa jalan yang ditunjukkan Hukum Taurat ialah jalan perbuatan.

"Mengejar kebenaran" (ayat 30) diganti "mengejar hukum kebenaran" (nomon dikaiosunes) (ayat 31). Orang kafir hidup seenaknya (ayat 30). Mereka "tidak mengejar kebenaran", dapat di isi dengan kecaman-kecaman yang terdapat dalam (1:1832). Mereka ini dinyatakan benar oleh Tuhan, bahwa mereka telah diterima Tuhan menjadi umat-Nya. ${ }^{53}$ Sebaliknya, (ayat 31) menegaskan bahwa Israel telah berlari mengejar kebenaran. Mereka telah berupaya sekeras-kerasnya melakukan hukum Tuhan, agar dinyatakan benar.

"Israel mengejarnya" merupakan sisipan. Terjemahan harafiah kalimat Yunani berbunyi: "karena bukan dari (ek) iman, melainkan seakan-akan dari perbuatan. Ayat 33 diambil dari (Yes. 28:16) digabungkan dengan (8:14). "Sesungguhnya, Aku meletakkan sebagai dasar di Sion sebuah batu," (28:16a) "batu sentuhan dan batu sandungan," (8:14b).$^{54}$ Dalam ayat 33a LAI tidak menampakkan perbedaan "lithos" dan "petra" (batu/bukit batu) dan (batu/batu besar).

"Sebuah batu", ini aslinya adalah gelar bagi Allah (Mzm. 18:1-2,31,46; Ul. 32:18; I Sam. 2:2; Mzm. 28:1; 31:3; 42:9; 71:3; 78:35), namun ini diambil menjadi gelar Mesias (Kej. 49:24; Mzm. 118:22; Yes. 8:14; 28:16; Dan. 2:34-35, 44-45; Mat. 21:42-44). Elemen kunci dari janji perjanjian Allah (Mesias) disalah mengertikan dan ditolak (1 Kor. 1:23). Orang Yahudi salah mengerti bukan hanya terhadap tujuan Mesias, namun syarat dasar dari perjanjian Allah. Kristus bagi orang Yahudi menjadi suatu sandungan (Yes. 8:14; Luk. 2:34), namun bagi orang percaya, baik Yahudi dan bukan Yahudi, Ia menjadi batu fondasi (Yes. 28:16; 1 Pet. 2:6-10). Ayat 33, berdasarkan kutipan (Yes. 28:16, tapi berbelat-belit karena (1) Menyisipkan beberapa kata dari (Yes. 8:14) sebagai ganti bagian tengah (Yes. 28:16); (2) Akibat sisipan itu dari nas asli diubah sama sekali, dari janji menjadi ancaman, meskipun bagian akhir (ayat 33b) tetap bernada janji (bdk. 1 Pet. 2:6-8). "Siapa yang percaya (kepada-Nya), tidak akan dipermalukan" Ini berasal dari (Yes. 28:16b). Ini juga dikutip dalam (Rm. 10:11) dan mirip dengan (Yoel 2:32), yang dikutip dalam (Rm. 10:13). Kunci keselamatan mencakup obyeknya (batu penjuru) dan penerimaan pribadi tiap individu (iman dalam Dia).

\footnotetext{
${ }^{53}$ Utley, Kumpulan Komentar Panduan, 194
} 


\section{KESIMPULAN}

Kedudukan Israel sebagai umat pilihan memiliki hak istimewa, khususnya hubungan mereka dengan Allah. Mereka telah diangkat sebagai anak, menerima kemuliaan, perjanjian, pemberian Hukum Taurat, dan Ibadah, serta janji-janji. Namun demikian keberadaan mereka sebagai umat pilihan ditolak dalam kerajaan Allah akibat ketidakpercayaan mereka terhadap Kristus. Orang Israel salah mengerti bukan hanya terhadap tujuan Mesias, namun syarat dasar dari perjanjian Allah. Kristus bagi orang Yahudi menjadi suatu sandungan, namun bagi orang percaya, Ia menjadi batu fondasi. Sanggahan Paulus ini sekaligus menjelaskan ajarannya mengenai predestinasi.

\section{DAFTAR PUSTAKA}

Barclay, William.Surat Roma Pemahaman Alkitab Sehari-Hari. Jakarta: BPK Gunug Mulia, 2003.

Brauch, Mafred T. Ucapan Paulus Yang Sulit. Malang: Seminari Alkitab Asia Tenggara, 2003.

Carlson, G. Raymond.Surat Roma. Malang: Gandum Mas, 1878.

Criswell, W.A.Tafsiran Alkitab Surat Roma. Jakarta: BPK, 1992.

Hagelberg, Dave.Tafsiran Roma dari Bahasa Yunani. Bandung: Kalam Hidup, 2000.

Henry, Matthew.Tafsiran Surat Roma, 1 \& 2 Korintus. Surabaya: Momentum, 2015.

Jaffray, R.A.Tafsiran Surat Roma. Makassar: Kalam Hidup, 1964.
Disinilah bahwa Allah tidak bergantung dari tindakan kita, tetapi Allah dalam menentukan pilihan itu muncul dari diri-Nya sendiri. Pilihan Allah tidak dimaksudkan untuk menyingkirkan, namun untuk mencakup Mesias akan datang dari benihyang terpilih, bagi semua (yang melakukan iman). Pemilihan Allah tidak dilihat dari perbuatan objek pilihan dan tidak tergantung objek, tetapi pemilihan Allah itu. Didasarkan atas kasih Allah kepada pilihanya atau kepada objeknya. Allah punya rencana penebusan bagi ciptaan-Nya, tak seorang pun dapat mempengaruhi rencana ini. Allah telah memilih untuk mengijinkan pribadi-pribadi untuk berpartisipasi dalam rencana-Nya. Kesempatan berpartisipasi ini adalah ketegangan teologis antara kedaulatan (Rm. 9) dan kehendak bebas manusia (Rm. 10).

Tasmara, K.H. Toto.Yahudi Mengapa Mereka Berprestasi. Jakarta: Publising Sinergi, 2010.

Tuluan, Ola.Introduksi PB. Batu: Departemen Literatur YPPII, 1999.

Utley, Bob. Kumpulan Komentar Panduan Belajar Perjanjian Baru, Vol. 5. Marshall Texas: Bible Lessons International, 2010.

Van Den End, Th. Tafsiran Surat Roma. Jakarta: BPK Gunung Mulia, 1995.

Van Der linder, S.Tafsiran Surat Roma. Bogor: BPK, Gunung Mulia, 1966.

Wiersbe, Warren W. Benar di Dalam Kristus. Bandung: Kalam Hidup, 1996. 